\title{
Risk Marker
}

National Cancer Institute

\section{Source}

National Cancer Institute. Risk Marker. NCI Thesaurus. Code C18493.

A characteristic that indicates the risk of developing a disease. 